\title{
Consequences of Post-Fascism in Security Policies in Spain
}

\author{
José A. Brandariz García \\ Law School, University of A Coruna, Spain \\ branda@udc.es \\ and \\ Patricia Faraldo Cabana \\ Law School, University of A Corunna, Spain/ Queensland University of Technology, Australia
}

\begin{abstract}
The paper analyses the features of the Spanish criminal justice system from the perspective of the late-democratisation condition of the Spanish polity. The text sees an almost uninterrupted expansionism and a relatively high level of severity as basic traits of the evolution of the Spanish criminal justice system. Consequently, the paper examines those features from the viewpoints of legal reforms, institutional practices and collective perceptions and expectations experienced since the end of the autocratic period. Finally, the article investigates some reasons which may explain the relatively high punitiveness of the Spanish criminal justice system, before adding a coda on the changes of the penal system fostered by the Great Recession.
\end{abstract}

Keywords: Spanish criminal justice system, democratisation process, punitiveness, sovereign mode of punishment, post-autocratic penality

\section{Introduction: Late-Democratisation and Penality in the Spanish case}

A suitable way to introduce a case analysis on the Spanish criminal justice from the perspective of the democratisation process may be by providing basic data on the historical background. The latest Spanish autocratic period ended in 1975. Therefore Spain may well be considered a country of late democratisation. This qualification appears to be even more appropriate if one bears in mind that during the two centuries of Modernity, Spain scarcely experienced any periods of actual parliamentary democracy. With the exception of the period beginning in 1975, only the brief lapse between 1931 and 1936, the time of the 
'Second Spanish Republic', may be considered an expression of that political system ${ }^{1}$. The other non-autocratic periods of the last two centuries witnessed simulated democratic regimes, organised around a model of power bargaining among the various elites, frequently accompanied by all manners of corruption and massive electoral frauds (Viejo Viñas, 2012). Therefore, the Spanish polity has undergone a late and 'low-profile' (Pisarello, 2003) democratisation, which cannot be disconnected from the conflictive and no less late integration of the country in the process of capitalist modernisation (Brendel and Simon, 2004; Vilar, 2004).

Moreover, two particularly peculiar elements contribute to characterise the Spanish polity as a late democratisation model. On the one hand, there is the extraordinary length of the most recent autocratic period, lasting from 1936 to 1975. On the other hand, the bargaining process which led to the current phase of democratisation, the starting point of which was actually a concession by the autocratic elites, not a political rupture (Campadabal, 2012; Grimaldos, 2013)2. The most direct implication of that peculiarity has been the inability of the current political system to define responsibilities for the massive human rights violations perpetrated during the Franco era, nor even to purge the dictatorship's administrative elite. All this has led to certain worrisome inertias in the operation of the Spanish polity, which have had also an impact on the criminal justice system (Jiménez Franco, 2014).

In terms of characterising the post-dictatorship Spanish criminal justice system, its most salient feature may be its amazing expansion, with a very remarkable and almost uninterrupted growth of prison population rates, as can be seen below in Graph 1.

\footnotetext{
${ }^{1}$ Throughout the 19th and 20th centuries Spain suffered 52 coups d'état.

${ }^{2}$ These features establish distinct differences between the Spanish autocratic experience and those undergone in Portugal and Greece. The last Greek dictatorship was far more brief (1967-1974). The Portuguese autocratic period was lengthier than the Spanish one (1926-1974); however, in contrast to both dictatorships, it was overthrown by a popular uprising (Carnation Revolution).

${ }^{3}$ It has been estimated that the Fascist regime led to the murder of some 200,000 people during the 1936-1939 Civil War (Beevor, 2001), and to some 25,000 murders thereafter, according to the Asociación para la Recuperación de la Memoria Histórica (Association for the Recovery of the Historical Memory) (El Mundo, 7 July 2002).
} 


\section{Secururity}

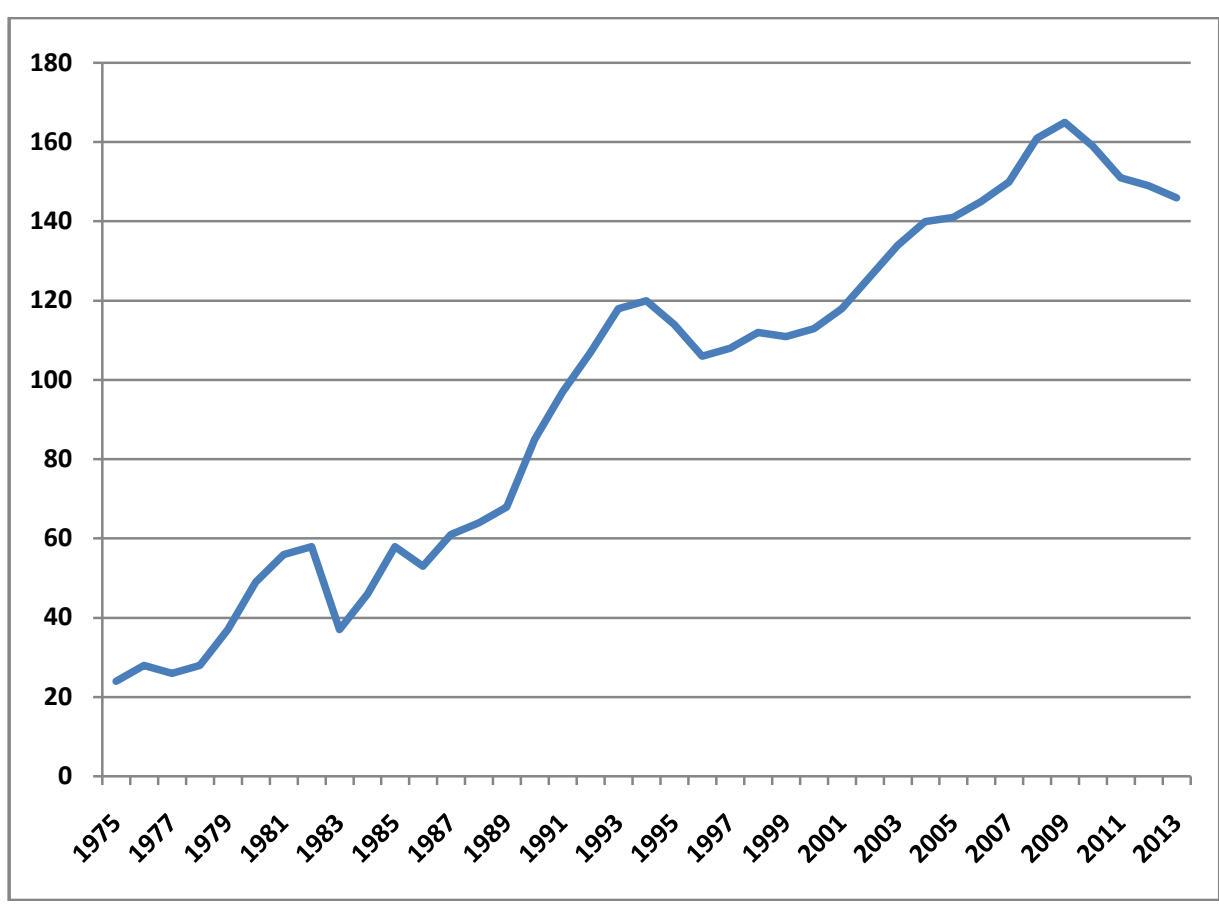

Graph 1: Evolution of Spanish prison population rate, 1975-2013

Sources: Carreras and Tafunell (2005) (1975-1989 data), Instituto Nacional de Estadistica (INE; National Institute of Statistics; www.ine.es) (1990-2011 data) and Secretaría General de Instituciones Penitenciarias (SGIP; Prison Service Office; www.institucionpenitenciaria.es) (2012-2013 data)

At the beginning of the post-dictatorship period these rates were amazingly low ${ }^{4}$. By contrast, since then Spanish prison population rates have become, especially during the last decade, significantly higher than those of the EU-15 countries, with the noteworthy exception of the UK ones.

${ }^{4}$ On the reasons of the surprisingly low prison population rates of late Francoism see Varona, 2000. 


\section{Security}

\begin{tabular}{lllllllll} 
& 1992 & $\mathbf{1 9 9 5}$ & $\mathbf{1 9 9 8}$ & $\mathbf{2 0 0 1}$ & $\mathbf{2 0 0 4}$ & $\mathbf{2 0 0 7}$ & $\mathbf{2 0 1 0}$ & $\mathbf{2 0 1 3}$ \\
France & 84 & 89 & 87 & 75 & 91 & 91 & 98 & 100 \\
Germany & 71 & 81 & 96 & 98 & 98 & 92 & 88 & 77 \\
Greece & 63 & 55 & 57 & 76 & 79 & 93 & 101 & 111 \\
Italy & 83 & 83 & 84 & 97 & 96 & 82 & 112 & 105 \\
Portugal & 97 & 123 & 147 & 128 & 125 & 109 & 109 & 137 \\
Spain & 105 & 115 & 113 & 114 & 137 & 147 & 166 & 146 \\
UK & 92 & 101 & 124 & 125 & 139 & 147 & 151 & 147 \\
\hline
\end{tabular}

Table 1: Evolution of prison population rates of several Western and Southern EU countries, 1992-2013

Source: International Centre for Prison Studies (ICPS; www.prisonstudies.org)

An additional fact evinces that the Spanish criminal justice system is characterised not only by a remarkable expansion but also by a comparatively high degree of severity: the crime rate. According to Eurostat, Spain has a delinquency rate notably lower than those of other major EU countries; though not lower than those of other Southern European countries (Ripollés, 2011).

\begin{tabular}{llllll|ll} 
& $\mathbf{1 9 9 5}$ & $\mathbf{1 9 9 8}$ & $\mathbf{2 0 0 1}$ & $\mathbf{2 0 0 4}$ & $\mathbf{2 0 0 7}$ & $\mathbf{2 0 1 0}$ & $\mathbf{2 0 1 2}$ \\
\hline France & 61,8 & 59,5 & 66,6 & 61,4 & 56,4 & ---- & ---- \\
Germany & 81,8 & 78,7 & 77,4 & 80,4 & 76,3 & 72,5 & 74,7 \\
Greece & 31,1 & 35,7 & 40,2 & 36,7 & 37,9 & 29,5 & 17,5 \\
Italy & 39,9 & 42,6 & 38,0 & 41,8 & 49,6 & 43,4 & 47,5 \\
Portugal & 32,6 & 33,7 & 36,3 & 39,8 & 37,6 & 39,7 & 38,2 \\
Spain & 42,2 & 47,1 & 50,7 & 50,6 & 51,9 & 50,0 & 48,5 \\
UK & 97,4 & 96,7 & 103,1 & 103,8 & 89,6 & 73,8 & 64,6 \\
\hline
\end{tabular}

Table 2: Evolution of registered crime rates in several Western and Southern EU countries, 1995-2012

Source: Eurostat (epp.eurostat.ec.europa.eu)

Following the most reliable literature (Matthews, 2009; Tonry, 2004; Wacquant, 2009), the apparent contradiction between low crime rates and high prison population rates 
cannot be interpreted in a causal manner: i.e. that greater penal severity is the cause of low delinquency level. In effect, the punitiveness of a criminal justice system is not a natural phenomenon but a constructed one, mainly the outcome of the complex interplay of three elements: legal reforms, institutional practices, and collective perceptions and expectations (Bell, 2011; Cavadino and Dignan, 2006; Western, 2006).

The analysis of the three elements may contribute to answer the questions arising from the post-dictatorship evolution. First, legal reforms, institutional practices and collective perceptions and expectations will be examined, so as to shape a fine-grained analysis of the expansionism and severity traits that have characterised the criminal justice system since the onset of the democratic period. Second, the paper will investigate some key historic, political, cultural and socio-economic features which may explain those peculiarities of the Spanish criminal justice system, and their relationship with the shortcomings of the democratisation process. As a coda, the paper will briefly analyse the changes undergone by the criminal justice system since the onset of the so-called Great Recession. Those different perspectives are not only aimed at understanding the evolution of the criminal justice system in relation to the democratisation process; they are also aimed at posing an arguably more compelling question: May the Spanish case be read as an example of a distinct type of penality, which might be called 'post-autocratic penality'?

\section{The Features of Post-Dictatorship Spanish Penal Policies: Legal Reforms}

A first explanation for the rising severity of the criminal justice system may be found in legal reforms, as Spanish penal laws have progressively hardened throughout the post-dictatorship period. While the abolition of the Franco-era Penal Code was considered a most urgent legal reform, the process of passing a new legal structure was extremely slow, lasting from 1980 to 1995. The claims of rehabilitation and penal leniency, so fashionable immediately after Franco's death (Medina-Ariza, 2006) had become outmoded twenty years later. The 1995 Penal Code is, generally speaking, harsher than the former one, particularly in regard to the most frequently prosecuted crimes such as property or drug-related crimes (lbáñez, 2003)5. Moreover, since 1995 dozens of legal reforms have made the penal

\footnotetext{
${ }^{5} \mathrm{~A}$ key reason of the harshness of the legal regulation was the abrogation of the redención de penas por el trabajo (early release through prison work), a prison programme established during Franco's rule by the 1956 Prison Service Regulation. The programme allowed the vast majority of inmates to
} 
legislation more and more severe, with very few exceptions. As a consequence, even though the passage of the 1995 Penal Code led to the immediate release of a limited number of inmates ${ }^{6}$, its harshness sustained the constant and significant increase of the prison population during the $2000 \mathrm{~s}$. A clear effect of the toughening of penal legislation has been the evolution of the average length of effective imprisonment: from 9.7 months in 1996 (Tournier, 1998) the figure rose to 17.4 months in 2009 (Aebi and Delgrande, 2012) 7 . Second, the legal reforms did not consolidate a diversified and widely-applied catalogue of community sanctions. In 2012 the prison sentence was still the most frequently applied sanction within the criminal justice system (25.5\% of sentences), above the fine $(19.4 \%)$ and the community service order (9.7\%), according to INE data. In 2014 probation is still only applied to juvenile offenders. Third, from the 1990s onwards there has been salient political and popular pressure to rise the maximum term of the prison sentence, in line with the 'truth in sentencing' shift in English-speaking countries. Consequently, in a criminal justice system with no (formal) life imprisonment sentence ${ }^{8}$, in 2003 a maximum term of 40 -years of imprisonment was approved. Due to the tightness of legal rules in this regard, it has been estimated that in 2010 some 350 inmates were serving prison sentences lengthier than the formal maximum term? .

\section{Post-Dictatorship Penal Policies: Institutional Practices}

In contrast to legal reforms, at the level of institutional practices is perhaps where the inertias of the autocratic period and the consequences of the lack of a deep political rupture are most acutely felt. In the realm of policing, the most striking feature of the Spanish case is the significant lack of accountability, which may be read as an effect of the

reduce the length of imprisonment by one-third, with the exception of inmates sanctioned by their inadequate behaviour.

${ }^{6}$ The number of inmates released due to the decriminalisation of certain criminal acts by the new Penal Code amounted to less than 1000 individuals (Herrero, 2010).

${ }^{7}$ Average length of effective imprisonment was the third longest in the EU in 2009, only below those of Romania and Portugal (Aebi and Delgrande, 2012).

${ }^{8}$ In October 2013 the parliament began the discussion of a Penal Code reform proposal that includes reintroduction of (formal) life imprisonment sentence. Life imprisonment was formally abrogated, and substituted by a 30-years maximum term of imprisonment, by the 1928 Penal Code, passed during the autocratic ruling of General Primo de Rivera.

${ }^{9}$ See GODPP, 2010. 
deficient democratic reform. As a consequence, in cases of police brutality and cases of police mistreatment and torture are unfortunately frequent, as confirmed by repeated Council of Europe's reports (Commissioner for Human Rights, 2013; CPT, 2013; Varona, 2000). Evidence of this is the frequency with which charges are pressed for assaulting or resisting a public officer, a charge habitually used by the police to conceal cases of brutality: according to INE official data, in 2012 this charge constituted the sixth most frequently sentenced crime in Spain (out of 81 crime categories) ${ }^{10}$.

In addition to all this, policing raises two more concerns. One key motive of preoccupation is the frequent use by riot police of rubber bullets, a weapon considered lethal by European Parliament reports (STOA Programme, 2000), which have produced a number of casualties among demonstrators since the onset of the democratic period ${ }^{11}$. Another important concern is the massive utilisation of ethnic profiling, a racist technique denounced by the UN and by several NGOs (García Añón et al., 2013; Open Society Justice Initiative, 2007) ${ }^{12}$, but upheld by the Constitutional Court (ruling no. 13/2001) ${ }^{13}$. Moreover, a particularly disturbing implication of the lack of police accountability is the frequent impunity of unlawful behaviour by police officers, including in the most serious cases: e.g., 47 police officers convicted of torture were pardoned by the Spanish government between 1998 and $2012^{14}$.

\footnotetext{
${ }^{10}$ In 201212,383 individuals were convicted of the crime of assault or resistance to public officer.

${ }^{11}$ It is estimated than since the end of the autocratic period 9 people have been killed and 30 have lost an eye due to police use of rubber bullets (see Stop Bales de Goma, 2013).

${ }^{12}$ According to Spanish Home Office data (Ministerio del Interior, 2013) $36.7 \%$ of the individuals arrested in 2012 were foreign nationals, whilst the foreign resident population in Spain that year amounted to $12.1 \%$ of the total population. Nonetheless, the actual disproportion of police interventions as regards national origin and ethnic background might only be assessed by taking into account the data of foreigners arrested for the civil offence of irregular stay in the country; yet these data are subject to official secrecy by the Home Office.

${ }^{13}$ In regard to the Constitutional Court ruling, the UN Human Rights Committee subsequently ruled on 27 July 2009 (communication no. 1493/2006) that the police use of ethnic profiling for purposes of detecting irregular migrants violates the right of non-discrimination and equality before the law set forth in article 26 of the International Covenant on Civil and Political Rights, and urged the Spanish administration to eliminate that particular police practice.

${ }^{14}$ On this, see elindultometro.es (accessed 7 April 2014). See also Commissioner for Human Rights, 2013.
} 
The judiciary system is marked by a constant and acute overload of work ${ }^{15}$, a burden that frequently leads judges to sideline the most rigorous observation of the right to a fair trial. The spread of a conservative judicial culture should be noted particularly among the higher ranks of the judiciary ${ }^{16}$. This context may well be influenced by the prominence of the Audiencia Nacional (National Higher Court), a contested special court principally devoted to terrorism cases $^{17}$. An apparent consequence of this conservative trend is the limited sensitivity of the judiciary to rights-based criminal justice. Perhaps the most conspicuous evidence of this is the Supreme Court's ruling (no. 197/2006) which extended the maximum term of imprisonment beyond what is prescribed by the Penal Code, a decision eventually overturned by the ECHR in 2013 (Del Río Prada v. Spain case).

The prison system is based on an essentially rehabilitative model, established by the 1979 Penitentiary Act. This law, not in vain the first legal reform enacted after the proclamation of the 1978 Constitution, set forth a formally welfarist prison model, outcome of two basic factors: on the one hand the memory of the imprisonment suffered during Franco's era by members of left-wing parties and, on the other, the remarkable influence of experts in preparing the reform (Rivera Beiras, 2006). In this sense, it may well be considered a unique experience in recent legislative history.

The post-dictatorship prison system has also been characterised by a high level of public spending in prison facilities ${ }^{18}$. Thus, in 1997 the prison system had an official capacity of more than 38,000 inmates (Tournier, 1998), while by 2013 this capacity had risen to

${ }^{15}$ See on this García España and Díez Ripollés, 2013.

${ }^{16}$ The conservative Asociación Profesional de la Magistratura (Professional Association of Magistrates) is by far the most widespread judges' association in Spain.

${ }^{17}$ The Audiencia Naciona/ is a court almost exclusively responsible for criminal matters. Indeed, it is the court responsible for the prosecution and judgement of cases of organised crime, particularly those associated with terrorism, drug-trafficking, money counterfeiting and economic crimes. Nonetheless, the vast majority of cases judged by the Audiencia Nacional are terrorism crimes. The Audiencia Nacional was created in January 1977, more precisely on the very same day that the autocratic Tribunal de Orden Público (Public Order Court) was abolished.

${ }^{18}$ Throughout the $1990 \mathrm{~s}$ and the 2000s a range of prison building programmes were implemented. The outcome of these programmes has been the in-depth renovation of prison facilities, and the substitution of urban small radial prisons with suburban or rural middle-sized modular prisons. According to Prison Service Office data, these programmes led to the opening of 20 new prison facilities between 1996 and 2011. Furthermore, between 2000 and 201225 semi-liberty prison facilities (named Centros de Inserción Social; Social Insertion Centres) were also inaugurated. 
more than 77,900 inmates, according to ICPS data. This economic investment has doubtless improved prison conditions and mitigated overcrowding, which in some periods attained a rate of $150 \%{ }^{19}$. Nonetheless, the prison system has failed to meet the rehabilitative expectations of the 1979 Act (Varona, 2000). The constant growth of the average term of effective imprisonment may be read as a clear evidence of that failure.

\section{Post-Dictatorship Penal Policies: Collective Perceptions and Expectations}

The reasons underlying the peculiar punitiveness of the criminal justice system may also be approached by looking at collective perceptions and expectations. However the image of these perceptions and expectations derived from CIS (Centro de Investigaciones Sociológicas, Sociological Research Centre) surveys is fairly ambiguous. According to these monthly surveys, 'urban safety' has been widely considered a serious problem by the population up to the beginning of the economic crisis, though it was much more of a concern in the 1980s and in the first part of the 1990s. Similarly, 'drug-related problems' and 'terrorism' tended to rate distinctly lower as serious popular concerns throughout the 2000 s than in previous decades ${ }^{20}$. In stark contrast to this evolution, urban safety did not gain currency in the political discussion until the 2000s, when its rhetorical connection with the remarkable migratory phenomenon of the decade facilitated its public salience (MedinaAriza, 2006) ${ }^{21}$.

\footnotetext{
${ }^{19}$ In January 2013 the official occupancy level was $88.0 \%$ (Source: ICPS).

${ }^{20}$ See on this www.cis.es (accessed 6 April 2014). According to most recent CIS data, in March 2014 'urban safety' was included within the three most serious national problems by just $2.0 \%$ of those surveyed, 'drug-related problems' by $0.1 \%$ and 'terrorism' by $0.9 \%$. In comparison with these figures, in February 2004 the results of the survey were 21.2\% ('urban safety'), 8.9\% ('drug-related problems'), and $40.1 \%$ ('terrorism'). In September 1993 the figures were 17.3\% ('urban safety'), 35.8\% ('drugrelated problems'), and $12.6 \%$ ('terrorism').

${ }^{21}$ Medina-Ariza (2006) points out that the cultural effects of the democratisation process and the overwhelming impact of terrorism prevented urban safety from taking centre stage in the political arena during the first decades of the democratic period. By contrast, the prominence of street crime in the public debate throughout the 2000s was facilitated by the interpretation of immigration as a social problem and by the widespread concern regarding gender violence. According to CIS data, 'immigration' was included among the three most serious national problems by more than the $20 \%$ of the individuals surveyed between 2005 and 2008.
} 
Regardless of all that, it has been contested whether the population might be considered highly punitive in comparison to other EU countries. The conclusion of a Spanish peculiarly high subjective punitiveness may apparently be backed by some European surveys ${ }^{22}$; however, authorised Spanish academic literature has consistently challenged this viewpoint (Varona, 2009). In addition, two major historical facts of the period under study may explain the prominent role played by criminal justice system in the management of collective anxieties and perceptions of social disorder. On the one hand, we see the extraordinary number of heroin addicts produced by society in the two decades following Franco's death. It is estimated that Spain had the highest rate of heroin addicts in the West; by the beginning of the 1990s they amounted to some 150,000 (Plan Nacional sobre Drogas, 2009), the vast majority of them involved in criminal activities (Gamella, 1997; Miró Miquel, 2005) ${ }^{23}$. On the other hand, throughout the first decade of this century Spain had the world's highest rate of immigration. More than 5.1 million foreigners (of them, more than 4.2 million non-EU-25 nationals) migrated to Spain between 2000 and 2010, and in certain moments of that period Spain had more than 1 million irregular migrants (Carrasco Carpio, 2008; Pajares, 2010). Without a doubt, the penal management of both phenomena contributed to the growth of the prison population between 1983-1994 and 1999-2009 (Rodríguez, 2003; Brandariz García, 2011) ${ }^{24}$.

Furthermore, Spain may well be a case study for testing the theories which point to the role of the criminal justice system in the management of surplus populations (Dean, 2010; De Giorgi, 2006; Rose, 1999). In effect, for long periods Spain has had unemployment

\footnotetext{
${ }^{22}$ In the European Social Survey, $5^{\text {th }}$ edn. (2010-2011) (www.europeansocialsurvey.org/), Spain rated as the country with the sixth highest level (out of 26 ) of fear of victimisation by robbery $(27.9 \%$ of the surveyed individuals). Spain showed the $5^{\text {th }}$ highest rate of agreement with the idea that rising punitiveness may be the best solution to tackle crime (76.2\%). See on this Torcal, 2012; see also Varona, 2013.

${ }^{23}$ As a comprehensible repercussion of this, a CIS survey found in June 1988 that $49 \%$ of those surveyed included 'drug-related problems' among the three most serious national problems.

${ }^{24}$ Between 1983 and 1994 the prison population grew by 337\% in global figures. Between 1999 and 2009 it rose again, this time by $72 \%$.
} 
rates much higher than those of other EU countries, over $15 \%$ of the working population between 1982 and 1999, and again from 2009 onwards $^{25}$.

\section{An Enduring Sovereign Mode of Punishment}

This quick review of several features of the criminal justice system demonstrates that this case study permits us to make a positive correlation between late democratisation and high punitiveness. In effect, the penal system appears to be remarkably severe and punishment-focused, in contrast both to welfarist and rehabilitative models and to economic-utilitarian and managerial models. In this sense, freely recalling Michel Foucault's (2007) work on punishment and power technologies, we may affirm that the penal system represents an enduring sovereign model of punishment.

The Spanish sovereign mode of punishment appears to be wholly consistent with some theoretical frameworks aimed at relating levels of punitiveness with socio-economic and political models, particularly Lappi-Seppälä's one (2011), which is focused on a wide range of European countries ${ }^{26}$. In effect, the Spanish case may well confirm his thesis, according to which low punitiveness correlates with countries with consensual and corporatist political cultures, high levels of social trust and institutional legitimacy and strong welfare states.

Consequently, the relatively high punitiveness of the system would be consistent with a fairly limited welfare state ${ }^{27}$ and with significant economic inequality ${ }^{28}$. Secondly, this

${ }^{25}$ The unemployment rate was more than 20\% from 1984 to 1987, from 1992 to 1997 and from 2010 onwards. In 2013 the average unemployment in Spain was 26.4\%, whilst that of the EU-28 was 10.9\% (Sources: INE, Eurostat).

${ }^{26}$ Lappi-Seppälä's model (2011) seems to be more suitable than other partially similar models. Cavadino and Dignan's (2006) 'radical pluralist' pattern does not take Southern European countries into account, and it deals with certain groupings of countries that seem questionable, at least since the onset of the Great Recession. The variables analysed by Lappi-Seppälä in regard to countries of high punitiveness are basically consistent with what Cavadino and Dignan classify as 'neo-liberal states'. On the other hand, Lappi-Seppälä's theoretical framework bears a resemblance to Lacey's model (2008), which connects high punitiveness with what she terms 'liberal market economies', characterised by two-party majoritarian political systems and by poorly redistributive welfare models, among other variables.

${ }^{27}$ Social spending amounted in 2011 to $26.1 \%$ of the GDP, a percentage below that of France, Germany, UK, other Mediterranean countries (Greece, Italy, Portugal) and the EU average (29.0\%). 
high level of punitiveness may be explained by pointing to the levels of social trust and political legitimacy of the country, which are fairly poor in comparison to those of the major EU nations, but to some extent similar to those of other Southern European countries ${ }^{29}$. Thirdly, Spanish punitiveness, following Lacey's (2008) and Lappi-Seppälä's (2011) analytical frameworks, may be also related to a political system characterised as fairly majoritarian, aimed at concentration of power and with reluctance to corporatism and consensus making ${ }^{30}$.

Nevertheless, the punitiveness of a given jurisdiction cannot be read as a mere effect of certain modes of organising and governing politics, the economy or the social, but primarily as the outcome of contextual and territorialised phenomena (Lappi-Seppälä, 2011). Therefore, we may suggest three additional explanations of the peculiar punitiveness of the Spanish system. Beyond Lappi-Seppälä's theoretical framework, these three additional traits, which bridge the gap between the autocratic past and the democratic present,

Social spending per capita in Spain (€6031 in 2011) also stands far below the EU average (€7260) (Source: Eurostat).

${ }^{28}$ The GINI Index in 2012 was 35.0, i.e, a level of inequality higher than that of Germany, France, UK, the rest of the Mediterranean countries and the EU average (30.6). Moreover, in $201228.2 \%$ of the population was at risk of poverty or social exclusion, a rate higher than that of the major EU countries and the EU average (24.8\%), but lower than that of other Mediterranean countries (Source: Eurostat).

${ }^{29}$ See the World Bank 2012 Worldwide Governance Indicators (info.worldbank.org/governance/

wgi/index.aspx\#home, accessed 6 April 2014), particularly by the indicators 'Voice and accountability', 'Political stability and absence of violence', 'Government effectiveness' and 'Rule of law'. Spain rates lower on all of them than Germany, France, UK and the OECD average, but equal to or higher than Greece, Italy and Portugal. In addition, the European Social Survey, $5^{\text {th }}$ edn. (2010-2011) found that Spain rates above average in terms of satisfaction with democracy and satisfaction with the police. In contrast, Spain lies below average in terms of satisfaction with the judiciary, trust concerning politicians, trust concerning political parties and interest in politics. The levels of institutional legitimacy seem to have fallen even further in the $6^{\text {th }}$ edition (2012-2013) of the survey (see El Pais, 14 January 2014).

${ }^{30}$ Lappi-Seppälä's work (2011) is based on the renowned analysis developed by Arend Lijphart (1999). According to him, the most prominent features of the Spanish political system are: a) a clear trend towards a two-party system; b) a model of one-party executive power; c) one of the most disproportional electoral systems of the EU. 
characterise the Spanish mode of punishment as a distinct expression of 'post-autocratic penality'.

First, the inertias of governmental modes pertaining to the autocratic period should be taken into account, consequence of the absence of a deep democratic rupture (Jiménez Franco, 2014; Varona, 2000). The alarming lack of accountability of system agencies is a consequence of these inertias. The striking use of governmental pardon (more than 10,350 pardons were given by the government between 1996 and $2013^{31}$ ) stands out as evidence of a persistent sovereign model of punishment ${ }^{32}$.

Second, the remarkable severity of the criminal justice system may be related to the contamination of the whole system by the exceptionalist practices (in policing, the judiciary, sentencing ${ }^{33}$ ) employed for the purposes of fighting terrorism (Lazarus, Goold and Coss, 2013; Paye, 2007; Zedner, 2009). Spain continues to be the EU country with the highest number of inmates convicted of terrorist crimes $^{34}$, and likely the only one which still labels and criminalizes the activity of prominent political parties as terrorism (e.g.,

${ }^{31}$ See elindultometro.es (accessed 12 March 2014).

32 On the relationship between pardon and amnesties and state sovereignty, see Madrid Pérez, 2014; McEvoy and Mallinder, 2013.

${ }^{33}$ Among the exceptionalist practices, the following ones should be mentioned: a) the passing of antiterrorism laws, aimed at disproportionately increasing the sentences of terrorism crimes; the creation of associative crimes - such as belonging to a terrorist organisation or unlawful association - the creation of crimes based on vague and evaluative subjective elements, which require the assessment of the personality of the defendant; b) the authorisation of incommunicado detention periods, the restriction of the right to a fair trial, the almost automatic enforcement of pre-trial detention, and the legalisation of the denunciation of 'repentant' former armed militants; c) the setting-up of highprofile and hardly accountable police units, and the setting-up of special courts responsible for the judgement of terrorism crimes; d) the creation of maximum-security prison facilities, aimed at isolating the inmates convicted of terrorism crimes, and the complete abandonment of the rehabilitation of the offender as the goal of the prison sentence (see Bergalli, 1997; Rivera Beiras, 2003).

${ }^{34}$ According to Home Office official data (Ministerio del Interior, 2013), by the end of 2012, 574 inmates (including pre-trial detainees) were imprisoned in prisons convicted or charged of terrorist crimes. These numbers have remained fairly stable throughout the last two decades, oscillating between 500 inmates and 700 inmates. 
Bateragune $\left.\operatorname{cas}^{35}\right)$. The corruption of the system due to this penal exceptionalism is particularly apparent in the extension of the maximum term of imprisonment and in the survival of maximum-security prison facilities, which the 1979 Penitentiary Act ${ }^{36}$ considered extraordinary and temporary.

The third hypothesis, just as important as the previous ones albeit more difficult to empirically demonstrate, may be qualified as 'dromological', to borrow a term coined by the French cultural theorist Paul Virilio (1986). It has to do with the accelerated character of post-dictatorship Spanish history. In effect, all of Europe witnessed extraordinary social, economic, cultural and political transformations during the last 40 years, but these mutations were experienced in Spain 'dromologically', that is, in a most accelerated way (García Delgado and Jiménez, 2001; Jiménez Franco, 2014). A country barely acquainted with welfare had to rapidly accept a post-welfarist social model. A country that scarcely experienced Fordism was thrust quickly into post-fordist production model (Jiménez Franco, 2014). The phenomena of controlling surplus population groups (heroin addicts and migrants) may be framed in this context of historical acceleration. The dromological evolution over the last few decades may have contributed to grounding a high level of punitiveness. In effect, the thesis which relates fear of crime and increase of punitiveness to a sort of late-modern angst (Garland, 2001; Bauman, 2006) may be most suitable to explain the Spanish context. Moreover, the penal system may be a good case study for testing Melossi's (2000) theoretical claim, according to which in certain historical periods characterised by exceptional transformations penal severity works as a primary tool for managing perceptions of disorder and social anxiety.

To sum up, the post-dictatorship Spanish criminal justice system may be understood as a distinctly sovereign penal model, arising from inertias left by an authoritarian political history, the contamination of the system by the exceptionalist treatment of certain criminal acts, and the role of penality in governing the sense of disorder arising from accelerated transformations.

\footnotetext{
${ }^{35}$ Both the Audiencia Nacional ruling no. 22/2011 (16 November 2011) and the Supreme Court ruling no. 351/2012 (7 May 2012) condemned some key leaders of the Basque separatist political party Batasuna as members of a terrorist organisation, due to their political activities.

${ }^{36}$ Some 1100 inmates - $2.0 \%$ of the whole prison population, excluding pre-trial detainees - were imprisoned in maximum-security facilities by the end of 2013 (Source: Prison Service Office).
} 


\section{Securiaty}

\section{Coda: Spanish Penal Policies since the Onset of the Great Recession}

The end of this historical evolution is the Great Recession. Since it began, the Spanish criminal justice system has encountered something heretofore alien to its development: the scarcity of public resources.

In May 2010 the Great Recession, begun some two years before, entered its deepest stage in the Eurozone, when severe private indebtedness became public debt. In May 2010 the prison population reached its highest number since the post-Civil War period: 76,951 inmates, equal to a rate of 164 . Then began a process unknown since the end of the Francoist autocracy: the number of inmates started steadily decreasing. Hence, the prison population decreased by $13.4 \%$ in overall figures from May 2010 to January 2014, downgrading its rate to 143 .

The why of the contraction process may only be located within the Great Recession context. Within this stark process of economic crisis and sharp cuts in public spending, the prison system had to adapt to the scarcity of public resources. By contrast, the how of this contraction of the system can only be hypothesised, due to absence of complete data. However, it should be highlighted that the decrease in the prison population has primarily affected foreign inmates ${ }^{37}$. It appears to be fundamentally consistent with the deportation data, which over the last period show a remarkable increase of deportations tied to penal reasons ${ }^{38}$. Hence, the increment of the rate of deportations of migrants recently released from prison and/or with a criminal record has been a key tool for reducing the prison population. Secondly, the recent contraction may be related to the reform of the Penal Code implemented in December 2010 by the Organic Law no. 5/2010 (Rodríguez and Larrauri, 2012). The reform remarkably downgraded the sentences for some drug-trafficking crimes; owing to the salience of these crimes in the prison realm, the reform has doubtless contributed to the current contraction of the system. In addition, the scarcity of public resources and the adaptation of the prison system to the Great Recession have entailed cutbacks of inmates' rights and the degradation of prison life conditions (Forero Cuéllar and Jiménez Franco, 2014).

\footnotetext{
${ }^{37}$ The average foreign prison population in 2009 amounted to $35.7 \%$ of the global prison population, whilst in January 2014 it had decreased to 31.4\% (Sources: INE and Prison Service Office).

38 The so-called 'qualified deportations', i.e., the deportations of migrants who have been recently released from prison or have criminal records, increased from 5564 in 2008 to 8809 in 2012, according to the Home Office data.
} 
The most pressing issue raised by the current situation is to what extent the Great Recession may have led to the opening of a new model of penality, more managerial and less sovereign and 'post-autocratic'. The insufficient data only enable a hypothetical answer. Nonetheless, if the cycle of economic recession/stagnation continues indefinitely, as may be expected, then it would be highly unlikely that the Spanish penal system would initiate a new phase of expansionism and carelessness with the limits of public resources, which have been its key traits since the end of the dictatorship.

\section{References}

1. Aebi M and Delgrande N (2012) Council of Europe annual penal statistics. SPACE I. Survey 2010. Strasbourg: Council of Europe.

2. Bauman Z (2006) Liquid Fear. Cambridge: Polity.

3. Beevor A (2001) The Spanish Civil War. London: Penguin.

4. Bell E (2011) Criminal Justice and Neoliberalism. Basingstoke: Palgrave-MacMillan.

5. Bergalli R (1997) The New Order in Spain and an Hispanic Perspective on the History and Meaning of Social Control. In: Bergalli R and Sumner C (eds) Social Control and Political Order. London: Sage, pp. 34-51.

6. Brandariz García JA (2011) Sistema penal y control de los migrantes. Gramática del migrante como infractor penal. Granada: Comares.

7. Brendel C and Simon H (2004) Ilusiones politicas y lucha de clases. Del antifranquismo al postfranquismo. Barcelona: Virus.

8. Campadabal P (2012) CT y política: la lucha por el punto medio. Del "pacto con el régimen, de entrada, no" a la victoria de la CT. In: Acevedo C et al. CT o la Cultura de la Transición. Barcelona: DeBolsillo, pp. 65-76.

9. Carrasco Carpio C (2008) Mercado de trabajo e inmigración. In: Izquierdo Escribano A (ed.) El modelo de inmigración y los riesgos de exclusión. Madrid: Foessa, pp. 213257.

10. Carreras A and Tafunell X (eds.) (2005) Estadisticas históricas de España. Siglos $X I X-X X$. Bilbao: Fundación BBVA.

11. Cavadino M and Dignan J (2006) Penal Systems. A comparative approach. London: Sage. 
12. Commissioner for Human Rights (2013) Report by Nils Muižnieks, Commissioner for Human Rights of the Council of Europe, following his visit to Spain from 3 to 7 June 2013. Strasbourg. Available at: wcd.coe.int $/$ ViewDoc.jsp?id=2106465\&Site=CommDH\&BackColorInternet=DBDCF2 \&BackColorIntranet=FDC864\&BackColorLogged=FDC864 (accessed 7 April 2014).

13. CPT (2013) Report to the Spanish Government on the visit to Spain carried out by the European Committee for the Prevention of Torture and Inhuman or Degrading Treatment or Punishment (CPT) from 19 to 22 June 2012. Strasbourg. Available at: www.cpt.coe.int/documents/esp/2013-08-inf-eng.pdf (accessed 8 April 2014).

14. Dean $M(2010)$ Governmentality, $2^{\text {nd }}$ edn. London: Sage.

15. De Giorgi A (2006) Re-thinking the Political Economy of Punishment: Perspectives on Post-fordism and Penal Politics. Aldershot: Ashgate.

16. Díez Ripollés JL (2011) Un diagnóstico y algunos remedios de la política criminal española. Teoría y Derecho 10: 171-188.

17. Forero Cuéllar A and Jiménez Franco D (2014, forthcoming). La cárcel española en (la) crisis. Mano dura y escasez. ¿Hacia la esquizofrenia punitiva?

18. Foucault M (2007) Security, Territory, Population. New York: Picador/Palgrave Macmillan.

19. Gamella JF (1997) Heroína en España (1977-1996). Balance de una crisis de drogas. Claves de Razón Práctica 72: 20-30.

20. García Añón J et al. (2013) Identificación policial por perfil étnico en España. Informe sobre experiencias y actitudes en relación con las actuaciones policiales. Valencia: Tirant lo Blanch.

21. García Delgado JL and Jiménez JC (2001) Un siglo de España: La economía. Madrid: Marcial Pons.

22. García España E and Díez Ripollés JL (2013) La Administración de Justicia según los datos: Especial referencia a la jurisdicción penal. Málaga: IAIC/Tirant lo Blanch.

23. Garland D (2001) The Culture of Control. Oxford/New York: Oxford University Press.

24. GODPP (2010) Desenmascarando mitos que sostienen el sistema penal. Available at: libros.otroderechopenal.com (accessed 12 March 2014).

25. Grimaldos A (2013) Claves de la transición 1973-1986. Barcelona: Península.

26. Herrero S (2010) La irresistible fascinación del Derecho penal. Abogados 61: 26-28.

27. Ibáñez E (2003) La expansión de la cárcel en España. Mientras Tanto 89: 139-157. 
28. Jiménez Franco D (2014) La burbuja penal: Mercado, Estado y cárcel en la democracia española. PhD Thesis, University of Zaragoza, Spain. Available at: asapa.files.wordpress.com/2014/03/la-burbuja-penal-dani-jimenez-tesisoct2013.pdf (accessed 18 March 2014).

29. Lacey N (2008) The prisoners' dilemma: Political Economy and punishment in contemporary societies. Cambridge: Cambridge University Press.

30. Lazarus L, Goold B and Goss C (2013) Control Without Punishment: Understanding Coercion. In: Simon J and Sparks R (eds) The SAGE Handbook of Punishment and Society. London/Thousand Oaks: Sage, pp. 463-491.

31. Lijphart A (1999) Patterns of Democracy. Government Forms and Performance in Thirty-six Countries. London: Yale University Press.

32. Madrid Pérez A (2014) El indulto como excepción. Análisis de los indultos concedidos por el gobierno español durante 2012. Revista Crítica penal y Poder 6: 110-133.

33. Matthews R (2009) Doing time. $2^{\text {nd }}$ edn. Basingstoke: Palgrave-Macmillan.

34. McEvoy K and Mallinder L (2013) Amnesties, Transitional Justice and Governing through Mercy. In: Simon J and Sparks R (eds) The SAGE Handbook of Punishment and Society. London/Thousand Oaks: Sage, pp. 434-462.

35. Medina-Ariza J (2006) Politics of Crime in Spain, 1978-2004. Punishment \& Society 8(2): 183-201.

36. Melossi $D(2000)$ Changing representations of the criminal. The British Journal of Criminology 40: 296-320.

37. Ministerio del Interior (1999) Anuario estadístico del Ministerio del Interior 1998. Madrid: Ministerio del Interior.

38. Ministerio del Interior (2011) Anuario estadístico del Ministerio del Interior 2010. Madrid: Ministerio del Interior.

39. Ministerio del Interior (2013) Anuario estadístico del Ministerio del Interior 2012. Madrid: Ministerio del Interior.

40. Miró Miquel G (2005) La política criminal del problema droga. Etapas del problema y consecuencias de las soluciones adoptadas. In: Rivera Beiras I (ed.) Política Criminal y Sistema Penal. Viejas y nuevas racionalidades punitivas. Barcelona: Anthropos, pp. 303-318. 
41. Open Society Justice Initiative (2007) / Can Stop and Search Whoever / Want". Police Stops of Ethnic Minorities in Bulgaria, Hungary and Spain. New York: Open Society Institute.

42. Pajares M (2010) Inmigración y mercado de trabajo. Informe 2010. Madrid: Ministerio de Trabajo e Inmigración.

43. Paye, JC (2007) Global War on Liberty. New York: Telos Press.

44. Pisarello G (2003). Constitución y gobernabilidad: razones de una democracia de baja intensidad. In: Capella Hernández JR (ed.) Las sombras del sistema constitucional español. Madrid: Trotta, pp. 129-150.

45. Plan Nacional sobre Drogas (2009) Heroína. Madrid: Ministerio de Sanidad y Política Social.

46. Rivera Beiras I (2003) La cárcel y el sistema penal (en España y en Europa). In: Bergalli R (ed.) Sistema penal y problemas sociales. Valencia: Tirant lo Blanch, pp. 351-393.

47. Rivera Beiras I (2006) La cuestión carcelaria. Historia, Epistemología, Derecho y Política penitenciaria. Buenos Aires: Del Puerto.

48. Rodríguez E (2003) El gobierno imposible. Madrid: Traficantes de Sueños.

49. Rodríguez J and Larrauri E (2012) Economic crisis, crime, and prison in Spain. Criminology in Europe 2: 10-13.

50. Rose N (1999) Powers of Freedom. Cambridge: Cambridge University Press.

51. STOA Programme (2000) Crowd control technologies. An appraisal of technologies for political control. Luxembourg. Available at:

www.europarl.europa.eu/RegData/etudes/etudes/stoa/2000/168394/DG-4-

STOA_ET\%282000\%29168394_EN\%28PAR02\%29.pdf (accessed 10 April 2014).

52. Stop Bales de Goma (2013), Informe 2013. Available at: stopbalesdegoma.org (accessed 12 February 2014)

53. Tonry M (2004) Thinking about Crime. New York: Oxford University Press.

54. Torcal M (2012) Resultados de la quinta edición de la encuesta social europea. Available at:

www.upf.edu/ess/_pdf/5a-ola/Datos/ResultadosQuintaEdicion_FINAL.pdf (accessed 22 March 2014).

55. Tournier P (1998) S.PACE I. Statistique pénale annuelle du Conseil de l'Europe. Enquête 1997. Strasbourg: Conseil de l'Europe. 


\section{Securilatity}

56. Varona D (2009) ¿Somos los españoles punitivos?: Actitudes punitivas y reforma penal en España. InDret 1.

57. Varona D (2013) Percepción y elección del castigo en España: Resultados a partir de la Encuesta Social Europea (5 ED.). Cuadernos de Politica Crimina/111: 145-193.

58. Varona G (2000) "Spain is different": Beyond an Invisible Criminal Policy? In: Green $P$ and Rutherford $A$ (eds) Criminal policy in transition. Portland: Hart.

59. Viejo Viñas R (2012) La dansa de Medusa. Barcelona: El Tangram.

60. Vilar P (1986) La guerra civil española. Barcelona: Crítica.

61. Vilar P (2004) Historia de España. Barcelona: Crítica.

62. Virilio P (1986) Speed and Politics: An Essay on Dromology. New York: Semiotext(e).

63. Wacquant L (2009) Punishing the Poor. The Neoliberal Government of Social Insecurity. Durham: Duke University Press.

64. Western B (2006) Punishment and Inequality in America. New York: Russell Sage Foundation.

65. Zedner L (2009) Security. London: Routledge. 